Article

\title{
Transformations for Resilient Rural Futures: The Case of Kaikōura, Aotearoa-New Zealand
}

\author{
Nicholas A Cradock-Henry ${ }^{1, *}$ (D), Joanna Fountain ${ }^{2}$ and Franca Buelow ${ }^{1}$ \\ 1 Governance \& Policy, Manaaki Whenua Landcare Research, Lincoln 7640, New Zealand; \\ buelowf@landcareresearch.co.nz \\ 2 Department of Tourism, Sport and Society, Lincoln University, Lincoln 7647, New Zealand; \\ Joanna.fountain@lincoln.ac.nz \\ * Correspondence: cradockhenryn@landcareresearch.co.nz; Tel.: +64-3-321-9901
}

Received: 7 May 2018; Accepted: 10 June 2018; Published: 11 June 2018

check for updates

\begin{abstract}
On 14 November 2016, a magnitude $\left(M_{\mathrm{w}}\right) 7.8$ earthquake struck the small coastal settlement of Kaikōura, Aotearoa-New Zealand. With an economy based on tourism, agriculture, and fishing, Kaikōura was immediately faced with significant logistical, economic, and social challenges caused by damage to critical infrastructure and lifelines, essential to its main industries. Massive landslips cut off road and rail access, stranding hundreds of tourists, and halting the collection, processing and distribution of agricultural products. At the coast, the seabed rose two metres, limiting harbour-access to high tide, with implications for whale watching tours and commercial fisheries. Throughout the region there was significant damage to homes, businesses, and farmland, leaving owners and residents facing an uncertain future. This paper uses qualitative case study analysis to explore post-quake transformations in a rural context. The aim is to gain insight into the distinctive dynamics of disaster response mechanisms, focusing on two initiatives that have emerged in direct response to the disaster. The first examines the ways in which agriculture, food harvesting, production and distribution are being reimagined with the potential to enhance regional food security. The second examines the rescaling of power in decision-making processes following the disaster, specifically examining the ways in which rural actors are leveraging networks to meet their needs and the consequences of that repositioning on rural (and national) governance arrangements. In these and other ways, the local economy is being revitalised, and regional resilience enhanced through diversification, capitalising not on the disaster but the region's natural, social, and cultural capital. Drawing on insights and experience of local stakeholders, policy- and decision-makers, and community representatives we highlight the diverse ways in which these endeavours are an attempt to create something new, revealing also the barriers which needed to be overcome to reshape local livelihoods. Results reveal that the process of transformation as part of rural recovery must be grounded in the lived reality of local residents and their understanding of place, incorporating and building on regional social, environmental, and economic characteristics. In this, the need to respond rapidly to realise opportunities must be balanced with the community-centric approach, with greater recognition given to the contested nature of the decisions to be made. Insights from the case examples can inform preparedness and recovery planning elsewhere, and provide a rich, real-time example of the ways in which disasters can create opportunities for reimagining resilient futures.
\end{abstract}

Keywords: resilience; disaster; earthquake; recovery; transformation; New Zealand 


\section{Introduction}

There is growing consensus that to reduce losses in the face of global environmental change, risks, and hazards, 'business as usual' is not an option; fundamental, often radical, and possibly rapid changes towards greater resilience are required to secure livelihoods and wellbeing [1-3]. Globally, losses from geo-climatic hazards events are increasing, driven in part by climate change, technological change, population growth, urbanisation, and political and economic instability $[4,5]$. These trends are likely to continue, putting additional pressures on policy-makers, researchers and practitioners to enable more strategic responses, reduce vulnerability and enhance resilience. While there is agreement on the need to explore these issues, we currently lack empirical examples and evidence from successful change processes in response to hazard events [6,7], particularly in rural settings [8]. To address this gap, the following study empirically examines the emergence of new networks, agents and institutions in a post-disaster context for a rural community, establishing a baseline for longitudinal assessment of rural recovery trajectories.

These insights are particularly relevant for New Zealand (Aotearoa) a small developed economy in the Pacific [9]. Aotearoa-New Zealand is seismically active. Over the last decade, the country has experienced four major earthquakes, as well as smaller events that have collectively impacted thousands of homes and households, businesses, and industries in both urban and rural settings; from the densely populated capital city Wellington, to dispersed regions, reliant on limited road and rail connections [10,11]. In September 2010, the first major earthquake in 80 years in an urban area struck Christchurch, the largest city on the South Island. This was followed six months later by a second, more damaging event in terms of property damage and loss of life [12,13]. An additional earthquake sequence in 2013 affected the productive agricultural regions of Marlborough-Blenheim, and then in late-2016, the most recent event occurred, its epicentre near a small coastal community on the South Island.

On 14 November, at 00:02 NZST 2016 (UTC: 11:02 a.m. 13 November 2016), a magnitude $\left(M_{\mathrm{W}}\right)$ 7.8 earthquake struck the east coast of New Zealand's South Island. Rupturing began on a fault near the small town of Waiau in North Canterbury [14], south-west and inland of the coastal community of Kaikōura, a popular tourism destination (Figure 1). The quake was shallow—approximately $15 \mathrm{~km}$ deep—but fast, the fault rupturing at a speed of $1.8 \mathrm{~km} / \mathrm{s}(6450 \mathrm{~km} / \mathrm{h})$ [15].

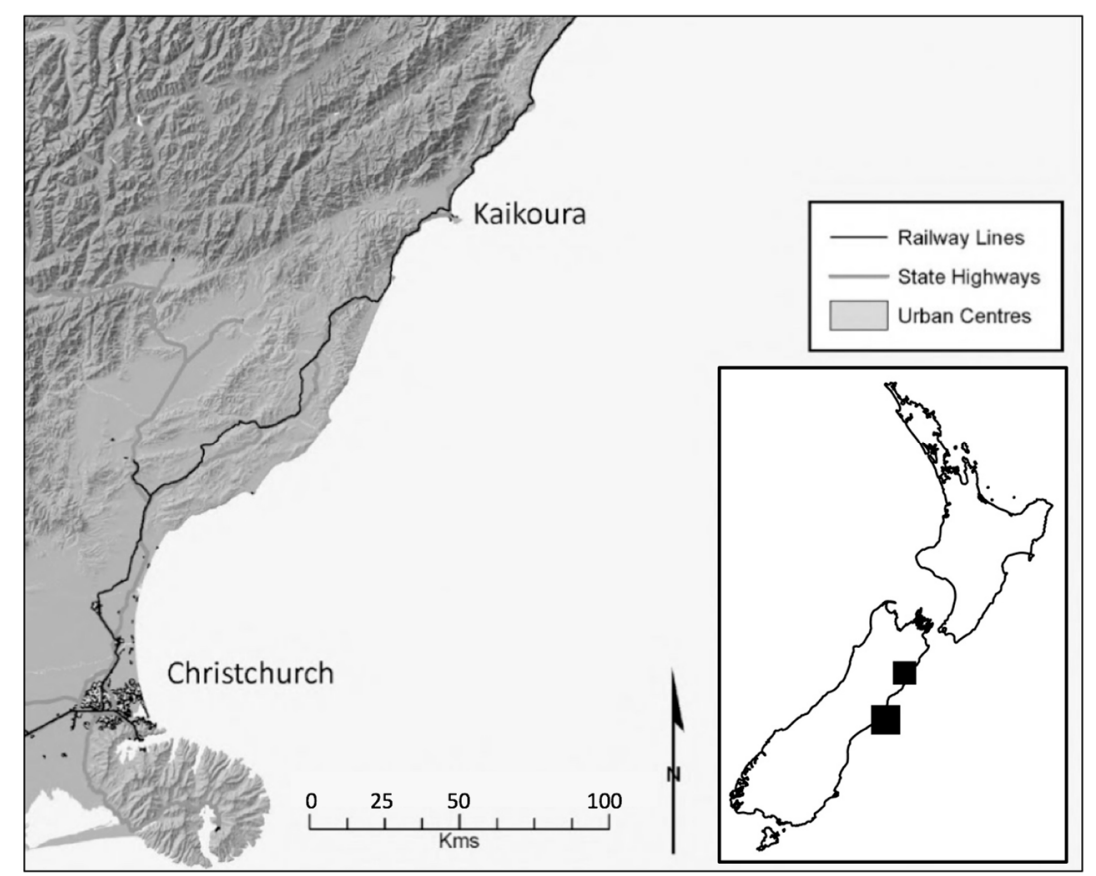

Figure 1. Kaikōura and surrounding area, South Island, Aotearoa-New Zealand. 
The earthquake-officially the Kaikoura-Marlborough-Hurunui sequence to delineate all affected regions-ultimately included the rupture of 21 faults across a span of approximately $180 \mathrm{~km}^{2}$ [16]. Two minutes of intense shaking were followed by four aftershocks exceeding $M_{\mathrm{w}}$ 6.0 [17]. Landslides were widespread (estimated between 80,000 and 100,000 separate slips) [14]. The coastline was physically transformed, the seabed rising approximately two metres, stranding some assets including boat launches (Figure 2). Critical infrastructure lifelines—road, rail, electricity, and telecommunications-and utilities such as domestic potable, and rural (stock) water supplies were cut off. The economic impacts were felt nationally, and will continue to be for some time with estimates for repair and rebuild as high NZ\$3 billion [16]. Locally, tourism expenditure dropped immediately. Compared to the same November-December period the previous year, domestic and international tourism expenditure in the region fell by $20 \%$, a loss of over NZ $\$ 21$ million [18].

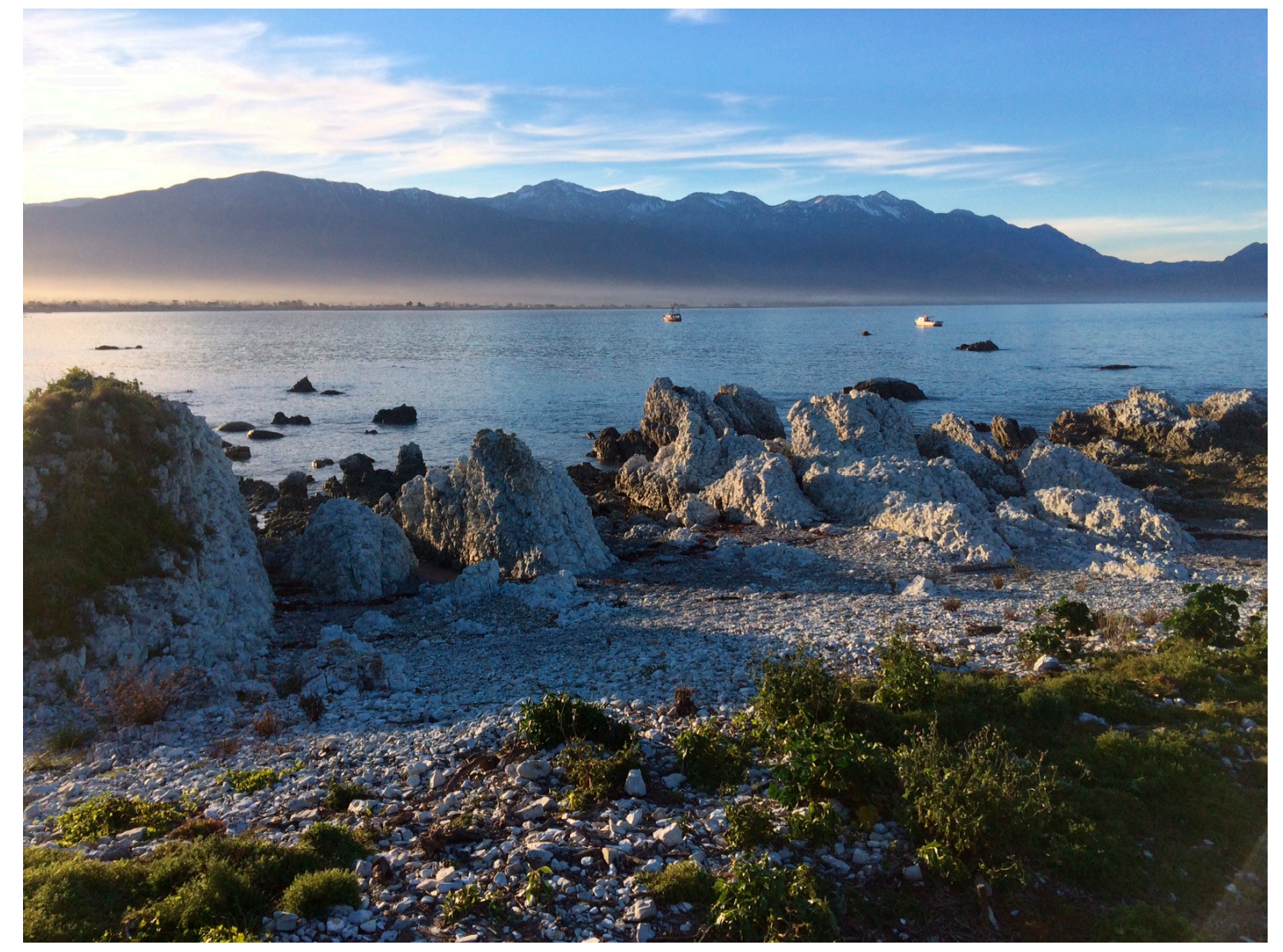

Figure 2. Coastal uplift near Kaikōura.

Two-hundred kilometres to the north, the capital city of Wellington was also affected $[15,19,20]$. Major office buildings and commercial spaces were permanently damaged, others were closed temporarily to assess damage. Potable water quality in the capital declined significantly due to increased turbidity, and major water losses occurred due to damaged pipes at the port, and wastewater treatment facilities [20].

Two fatalities and over fifty injuries were reported in the Kaikoura region, and damages were widespread. Throughout the dispersed rural support communities in the region, the earthquake levelled homes and damaged buildings, badly affected road and rail access with implications for the tourism and agriculture- the primary economic activities that underpin the local economy [16,21]. In Kaikōura township, with road access cut off excessive demands were placed on the local community and its normally resident population of only 2500 persons [22]. 
State Highway 1 (SH1) — the coastal road providing a north-south link for Kaikōura—was shut on either side of the community due to severe landslides and surface deformation. To the north of town, it would remain closed for over a year. The highway runs the length of the country, supplemented by a ferry crossing between Picton (South Island) and Wellington (North Island). It is the main link between Picton and Christchurch, and to the rest of the South Island, carrying substantial volumes of traffic and goods, and is also a popular tourist drive.

In response to these earthquakes and other recent damaging hazard events-including earthquakes, wildfire, snowstorms, and prolonged drought—-there is widespread interest among government, policy-makers, and practitioners in New Zealand in enhancing resilience, reducing vulnerability, and encouraging greater adaptability throughout society (natural, social, cultural, and economic systems) [9]. These events have strengthened a focus in research and policy on the need to better understand, prepare for, and respond to hazard events at a regional level [23]. The goal of a 'resilient New Zealand' has been the basis of government policy for almost two decades, beginning with the 2002 Civil Defence and Emergency Management Act. However recent disasters have highlighted the continued vulnerability of productive assets, economic activities, communities and wellbeing [24-27]. Earthquakes and other hazards have direct impacts in terms of lives lost and livelihoods, as well as flow on effects for primary production and productivity, tourism, and capital investment $[11,27,28]$. This has significant implications for a country reliant on international trade, capital markets, and its destination image.

As part of a larger project exploring rural resilience to environmental risks and hazards in Aotearoa-New Zealand [23], we discuss post-quake transformations in Kaikōura. Resilience and transformation provide frameworks with which to analyse the ways in which people, institutions and activities reorganise in response to external shocks or stressors, such as natural hazards. We illustrate how rural actors adapt to such shocks, in one case addressing regional food security, in the other enhancing rural recovery and response capability, and community wellbeing. The cases provide insight into the ways rural industries and communities might build resilience to natural hazards. They demonstrate how rural areas might thrive in the face of nature's challenges and potentially address limitations relating to peripherality (e.g., limited communications infrastructure, resource constraints, or centralisation of governance and decision-making powers) by exploiting opportunities to 'build back better' [29]. Furthermore, findings from the case studies challenge the normative interpretation of transformation equating novelty and newness with improvement. This empirically grounded analysis of rural recovery dynamics provides a means to share lessons and insights on the practice implications of resilience and transformation, drawing on insights from different disciplines and diverse contexts through structured examination of the ways in which change occurs [30-33].

The paper is organised as follows: a discussion of resilience and transformation is next. In it, we draw on the concept of adaptive cycles to consider the dynamics of reorganisation after a disaster, and the need to reduce immediate vulnerability to increase resilience and transform a current unstable state $[30,34,35]$. Section 3 describes the case-study setting, methods of data collection and analysis. The paper uses a qualitative methodology based on 12 in-depth, semi-structured interviews and two focus groups with affected stakeholders, supported by literature review and document analysis. Finally, the results of the empirical research are discussed as two shorter case examples, followed by summary and conclusion.

\section{Resilience and Transformation}

Resilience thinking has gained prominence in the fields of emergency management, disaster risk reduction, and environmental science $[1,34-37]$ as a perspective on the ability to cope with external shocks and stressors. Resilience resonates with policy makers and researchers alike, and is often viewed in normative terms [3,36] —as a commitment to "become more resilient" [38]. Resilience has been criticised for its theoretical opacity [38], nevertheless it is a powerful explanatory framework for 
understanding responses to challenges, and is now applied in diverse contexts and across fields of study from psychology $[39,40]$ to natural resource management [41-43].

Resilience is also closely linked to adaptation and vulnerability [35]. When exposed to shocks or stresses, adaptation is required to reduce vulnerability; lowering a system's defenselessness or susceptibility to damage or disruption [44]. Becoming more resilient entails reorganising damaged or affected functions and processes and redistributing or reallocating resources in response to shocks and stressors. In our study, this involves the reorganisation of rural actors and institutions following a large-magnitude earthquake, including tailored response mechanisms providing for characteristic functions (such as agri-food production and tourism) as well as processes (such as community wellbeing and rural decision-making) to take place now and in the future.

In empirical studies of resilience the analytical focus is often on a social-ecological system; the assumption being that a system-be it a productive activity, a community, or region-includes both social (human) and ecological dimensions [30]. Sometimes referred to as coupled human-natural systems [45], or coupled socio-environmental systems [46], they incorporate the environment and human activities through land, water or hazards management practices, land use, or ecosystem services $[30,47]$.

In resilience thinking, a social-ecological system may have multiple possible configurations: stable states in which component parts function. Over time, such a system advances through different stability landscapes, or equilibrium states, as part of an adaptive cycle [48]. As it shifts through different equilibria, the resilience of the system is dynamic, determined by the breadth and depth of change as well as type of change at any given point. Resilience is often defined therefore as "the capacity of a system to absorb disturbance while undergoing change so as to still retain essentially the same function, structure, identity, and feedbacks" [30]. Processes of adaptation and transformation are complementary; transformation at one scale can maintain resilience at other scales [30,49]. Conceptually, such a relationship of resilience dynamics is often captured with reference to the adaptive cycle, consisting of four phases: exploitation; conservation; release; and reorganisation [50]. Typically, this involves long periods of growth, maturation, and stability followed by rapid destruction, in which the existing equilibrium is disturbed. Following a disturbance, a period of reorganisation follows during which the system regenerates and recovers [51].

Those disturbances-whether slow-onset, creeping hazards such as drought, or low-frequency, high impact events like earthquakes - have the power to change previously stable states in powerful and unexpected ways [52], including widespread reorganisation into something new [50]. Disasters, for example, can overwhelm the capacity to maintain structures, and so fundamentally impact vital functions and processes that it is impossible to return to normal; the regime shifts $[34,50,53,54]$ and a new adaptive cycle begins.

Disasters often are associated with a window of opportunity for regeneration, recreation, and re-imagination [55]. The precariousness, however, between the new and the old systems-between conservation and release-is critical. Depending on the nature of the shock, and of pre-existing conditions, it may simply fall back into its original regime, transition to a new and improved system, or transform into something much more original, representing wide-spread, systemic change $[30,34,50,56]$.

Transformation, in which widespread or systemic changes are made to existing decision-making processes and patterns, is often experienced following a disaster, even if only briefly before systems fall back into pre-existing forms and structures $[34,57,58]$. Many adaptive management strategies fail to be successfully implemented or bring about transformative changes due to existing governance structures that hinder their realization for example [30,34]. Disaster governance, conceptualised as the management process of hazards, has a profound social dimension in which we learn from experiences with disasters and respond with improvements in governance via diverse, decentralised and multi-scalar involvement [59]. One aspect of this can include involving affected people in designing and deciding on future options. This in turn can empower them to develop inclusive solutions and 
enhance resilience [60-62]. Communities of practice that arise from such interactions codify learning processes in "shared practices, tools, concepts, symbols, or material artefacts embedded in a context of meaning" [63]. Such communities can develop location-specific, group-specific and time-specific coping pathways and structures within a vulnerable environment [64,65]. Embracing opportunities for learning from community experience and expertise in dealing with risks as a part of formal response mechanisms-for example an exchange on regional and local best-practice examples of adaptation—can in turn lead to a transformation of habits [34,66,67].

Institutions are both a steady influence and a reflexive structure shaped by individual and structural developments. Institutions mirror actions, but they also constitute the structures that influence an actor's behavior [68]. What may appear to be a resilient system can hold power structures, inequities, and exclusions in place that create "rigidity traps" [34,57]. Therefore, transformation is all-encompassing, involving shifts in meaning, perception, social networks, patterns, and institutional and governance arrangements including changes in leadership and power relations [34].

The following section documents the impacts of the Kaikoura earthquake and its implications using two case examples to explore the ways in which the shock is catalysing a new equilibrium. The system-including the rural population in the area, their households, networks, formal and informal governance, and institutional arrangements-is now navigating the transition between conserving the previous, legacy system, and moving towards a new one. Together, these case studies provide an empirical account of transformations following a disaster in the context of a rural region, within a developed economy.

\section{Case Studies in Transformation}

\subsection{Context}

Kaikōura is located on the east coast of the South Island, Aotearoa-New Zealand. The surrounding district covers an area of approximately $2000 \mathrm{~km}^{2}$, bounded by an inland range to the west, and the Pacific Ocean on the east (refer to Figure 1). It is New Zealand's smallest mainland district by area as well as the lowest rating base in the country, which limits revenue from property valuation.

The region's mottos-'Where the mountains meet the sea' and the 'Maritime Serengeti' - refer to the abundant opportunities for recreation and wildlife viewing. [69] Tourism is a major economic driver, employing over $25 \%$ of the population, with an additional 15\% in retail occupations (Census 2013). Commercial whale watching began in the 1980s and marine-based tourism has since grown to include swimming with dolphins and seals, diving, and fishing charters. In this way, the tourism industry dominates the local economy [70,71]. Kaikōura is a popular destination with international and domestic visitors, hosting over 125,000 visitors annually, in part due to its location halfway between Christchurch and Picton where ferries depart for the North Island [72]. Primary industries including agriculture, forestry, and fishing are still important (12.1\% of employment), despite the closure of the local dairy factory shortly before the earthquake.

\subsection{Methods}

The research, on which these case studies is based, was conducted in and around Kaikoura between December 2017 and April 2018. Kaikōura had been identified prior to the 14 November 2016 earthquake as a case study site to explore issues relating to rural resilience as part of a larger, national research program on risks and hazards [23]. The community is exposed to multiple hazards including tsunami, wildfire, earthquake, and landslides; it is accessible to Christchurch (where the majority of the research team were located); there were pre-existing relationships with key stakeholders; and a local economy based on primary activities, including nature-based tourism. In sum, Kaikōura exemplified many of the challenges facing rural communities throughout New Zealand, including structural change, out-migration, and a dynamic physical environment. 
Data were gathered in stages by the authors, drawing on existing networks and knowledge acquired through previous research in the region. Methods used included semi-structured in-depth interviews $(n=12)$ and two focus groups. Secondary data was drawn from a review of local and regional policy and planning materials and directories (e.g., local business listings, promotional tourist material) to help contextualise the research findings, along with situation reports describing the immediate damage post-quake and recovery progress. The first interviewees were selected based on existing research collaborations with local council and emergency management staff. Subsequent to that, a snow-ball strategy was used to identify further participants representative of the range of affected interests, making this a convenient sample (e.g., food producers, regional economic development staff, and local government). Since interviewees were selected based on their roles and involvement in the recovery process, we could not guarantee gender, age, nor ethnicity. Kaikoura does have a significant indigenous (Māori) population, who were actively involved in elements of the recovery. Sensitivity to other work underway in the wider research programme, as well as limited capability and capacity for bi-cultural work precluded our developing this aspect in the current paper (see e.g., [73] for detailed considerations of working with Māori communities in a post-disaster context). Interviews lasted from approximately $30 \mathrm{~min}$ to two hours and were conducted in a location to suit the interviewee, including people's homes or places of work (often the same) and cafés.

Two focus groups, of five and seven people respectively, were also conducted. Protocols for effective focus groups were followed [74] including group size and composition. The size of the focus groups were appropriate and diverse enough to encourage rich discussion [75]. As with the interviews, focus group participants were representative of the stakeholders to the issues being investigated and invited on that basis. Attendance was dependent on availability and interest and each lasted approximately $90 \mathrm{~min}$. To assess the changes in activities, decision-making processes and priorities in the months following the earthquake, the same semi-structured interview schedule was used to solicit respondents in individual interviews and focus groups. Information was sought about impacts of the earthquake, their response to it, and ways in which existing decision-making processes, activities, networks, and institutions had either changed or new ones established. Interviews were audio-recorded, with the permission of the participant(s), and then transcribed verbatim. One focus group was audio-recorded and transcribed. In the few cases interviews were not recorded, detailed notes were taken. Socio-economic conditions and non-earthquake related factors that may have influenced them were documented, and contextual information supplied the review of secondary data. Repeated field visits, and documentation of changes in the community through parallel research helped empirically ground the analysis [76], and is consistent with other studies of resilience and transformation $[77,78]$.

Transcript data were coded by the authors using deductive and inductive methods [79]. Themes were identified in advance and emerged through the process of data analysis [80] which involved individual researcher engagement with the data, followed by a series of meetings of the researchers to compare and discuss individual conclusions.

The remainder of the paper focuses on the manifestation of transformation through two case studies and asks: How does transformation occur following significant shocks or stresses? The first discusses the role of new initiatives aimed at transforming agri-food networks to enhance local food security; the second explores the emergent transformation—and associated challenges—of confronting embedded and established norms and institutional arrangements for responding to disaster in a rural context. In both cases, individuals and communities are making significant changes that involve the mobilization of assets, networks, and social capital in response to disaster.

\subsection{Transforming Food Networks for Resilient Food Futures}

Kaikōura's identity has long been associated with the abundance of food available from the land and water surrounding the district. The area owes its name to the Māori explorer, Tamaki te Rangi, who, on arriving in the district tired and hungry, was relieved to find an area abundant with crayfish. 
He named the area "Te Ahi Kaikōura a Tama ki Te Rangi" — "the fire that cooked the crayfish of Tama ki Te Rangi", later shortened to Kaikōura (kai meaning food and koura meaning crayfish) [69]. Evidence from subsequent Māori settlement in the area (ca. 950-1130) reveals a diverse horticultural and fishing heritage, a tradition which continued with the arrival of European settlers in the 1830s and which persists to the present time through the farming and fishing sectors [81].

The felt impacts of the earthquake had significant implications for food security in Kaikoura District. With road and rail access cut off due to thousands of landslides north and south of town [21], an inland route (State Highway 70 [SH70]) became the main transportation link. This secondary road reopened within days but was subject to frequent closures, considerable travel delays, and limited opening hours for months following the event. Reliance on the inland route also impeded traffic flows and lengthened travel times resulting in significantly higher freight rates. For primary producers, frequent road closures and delays had adverse effects on the collection, processing, and distribution of agricultural products from sea and land including milk, seafood, meat, and wine [16].

The issue of food security became apparent almost immediately in the days following the earthquake, as the district's residents experienced a lack of fresh food, including meat, fruit, and vegetables. Furthermore, thousands of tourists were stranded in the town, placing additional demands on limited supply [22]. Local residents recognized the irony of living in an agricultural district, with plenty of livestock, but with no means to access the meat, as the district lacked a compliant processing plant. At the same time, the 24 dairy farms in the district were forced to dump thousands of litres of milk each day for three weeks, due to the inability of tankers to access their farms [16]. In a region renowned for its seafood, the uplift of the seabed had exposed an abundance of marine life, including cray and shellfish, but a rāhui (a tapu, restricting use of, or access to an area) imposed due to concerns about contamination meant this source of fresh food was also out of bounds (Figure 3).

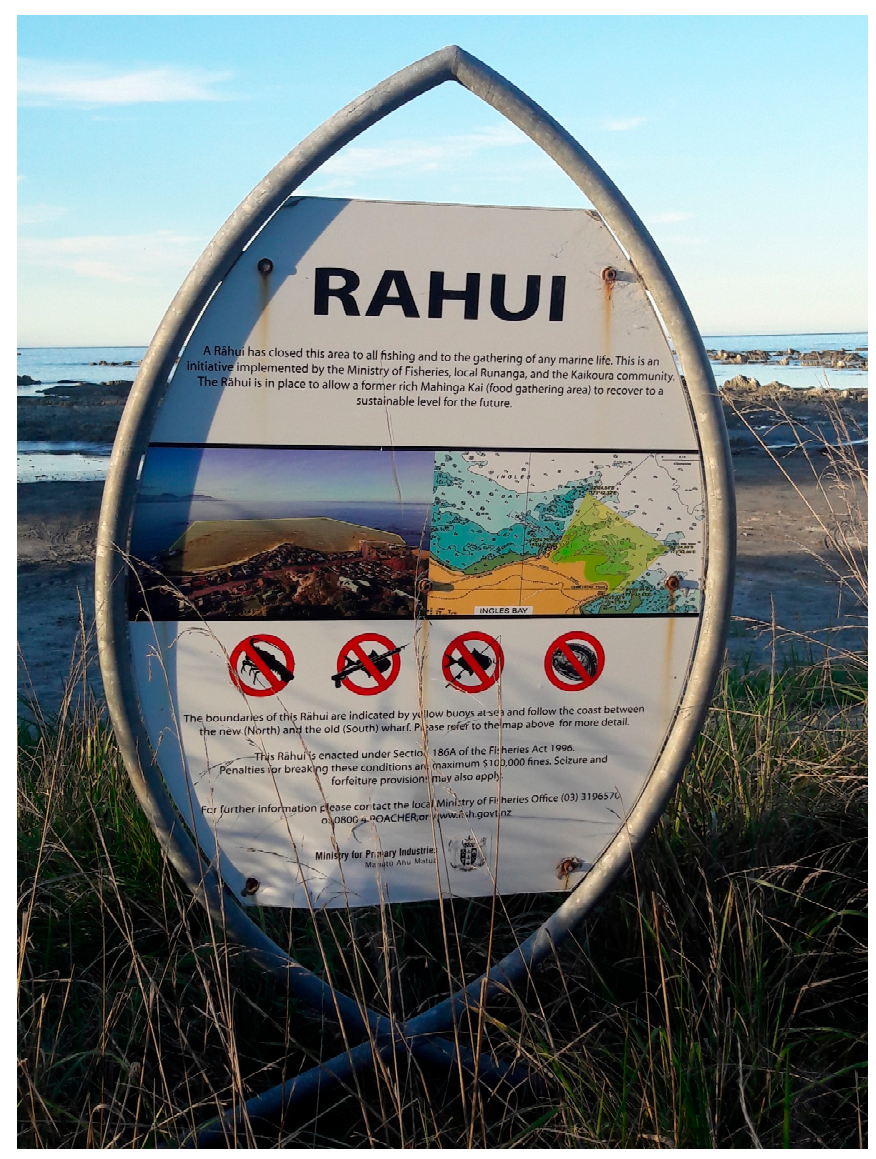

Figure 3. Restrictions (tapu) on harvesting put in place following the earthquake. 
Helicopter food drops and food convoys soon followed, organised by both formal and informal agents and actors (e.g., Miss Lilly's Trust, following section). An early delivery of fresh food came as a result of a food relief mission organized by a food producer in Amberley, $140 \mathrm{~km}$ south of Kaikōura, who packed an inflatable dinghy with food and made a challenging journey around the coastline to deliver the produce.

A council employee described the situation in the following terms:

It was only people who had homekill (In New Zealand, homekill refers to the slaughter and butchering of farmed or wild animals to be consumed by you, your family and household, any farm workers you employ and their family and household.) who had fresh meat. Everyone else had to live off ... sausages. In terms of vegetables, everyone was sharing .... From a resilience perspective it really highlighted that we have a really good homekill guy here, but commercially he couldn't actually kill ... . It was the same with the milk; we were tossing away hundreds of thousands of litres a day, because you can't sell it for human consumption. So a lot of people were coming up to the farm gate and got it, and they were advised to heat it up to 70 degrees ... so there was a lot of that sort of stuff going on.

Even today, eighteen months after the earthquake with road networks reestablished, businesses face significant problems with consistent access to produce. As one café owner reported: "We are finding ... difficulty in getting freighters to commit [to delivering fresh produce] ... it's hit and miss ... They won't come if they have to come through the central route [SH70]".

In resilience thinking, there is evidence to support the observation that disruptions-whether environmental, economic, or social in origin - can also be windows of opportunity for transformation $[34,82,83]$. Shocks may open a social-ecological system to new opportunities, providing the impetus for reflection, revaluation, or act as catalysts for innovation and novelty $[31,34,84]$.

We found growing awareness of the need to reevaluate local food security following the earthquake; to reconsider food security collectively-as a community-rather than an as a responsibility of individuals or households. As one informant put it, "people are thinking outside the square". From a resilience perspective, this is an emergent transformation towards greater levels of self-organisation, in which local opportunities and connectivity is enhanced between the district's individuals, businesses, and rural and urban communities. Rather than looking outward or increasing its reliance on fragile and exposed transportation networks, the focus is inward. As one council employee involved in the recovery put it, "To be honest, Kaikōura could have survived for a long time quite happily if we had been a bit more organized... [if we were] able to get round any rule ... ".

To realise the transformation towards more resilient food networks in the region, two critical developments were identified. The first involves building local capability and capacity for food security through establishing new networks and knowledge sharing. The second involves identifying and challenging existing institutional and governance arrangements at multiple scales, which inhibit (even during emergency) local food distribution/access.

The sharing of resources following the earthquake enhanced awareness of the range of locally available food products and equipment in the community, but also highlighted the lack of formalized networks and processes for accessing them. While a local farmers market operated in the community prior to the earthquake, membership fluctuated, it had limited reach, and low visibility in the community. Members of this network however have been instrumental in developing new distribution channels, networks, and marketing opportunities post-disaster. As part of the Kaikōura District Recovery Plan [69], there is an acknowledgement of the need to develop community resilience. The plan-Reimagine Kaikōura-includes a 'Kaikōura Gets Ready' resource for individuals, households and businesses which identifies actions people can take to support themselves and others in times of hardship. Knowledge of food resources could be part of this documentation. As someone involved in this process explained, "We will know what things we have available... We can expand that to include all this stuff that is in the background, is what I was thinking". In interviews and focus group discussions, 
additional ideas were proposed to include in this resource: information about food supplies and suppliers; generators; off-grid cold storage facilities and freezer units which would not be vulnerable to electricity outages; olive oil presses; guns, ammunition, and licensed hunters who might be able to target wild rabbit and deer. As one informant explained, "we've got a gazillion rabbits... So who's got ammo to shoot the rabbits? Because we could feed the whole community on rabbit forever." However, the value of developing these lists or networks went beyond emergency preparedness to general resilience and capacity building by bringing community members together to utilize existing food resources in an ongoing collaborative way.

Other suggestions-this from a local event organizer-were to hold a variation of a harvest festival: "At harvest time, everyone has got all this fruit falling off the trees ... so as a community, moving into the hall ... let's share it around. Let's make an event of it". The aim would be to organize activities for community members who would spend time together canning fruit, and preparing jams, soups or chutneys in a communal setting. Such an event would enable people to come together to share resources and resupply cupboards while having fun and building social networks. This opportunity to build capability and capacity through the acquisition of new skills, and knowledge sharing would enhance community resilience. Appropriate licensing and food safety plans organized by the local council would provide potential pathways to sell the finished products through local farmers markets and other retail outlets in the area.

One of the barriers to this type of transformation for local food security is compliance, including the (non-)distribution of local resources due to food regulatory standards. These issues are not new but were highlighted and exacerbated in the aftermath of the earthquake, when milk was being discarded and homekill operators could not distribute meat commercially. As one informant explained:

Chatting to [the man] who does our homekill ... for him to do commercial he has to set up a whole separate building to do the exact same thing to do commercial. He can't do it through his existing abattoir ... so it is not worth him setting up the facilities.

A similar issue exists in the fishing industry:

One of the silly things is with the fish caught here, it has to go down to Christchurch and back up for the restaurants to buy, they can't just buy local fish here ... Getting through the red tape that requires that jolly fish to go down to Christchurch and then back up here. I mean ... the carbon footprint ...

The issues regarding food compliance are closely linked to other, structural changes in the community. In the two years prior to the earthquake, both the milk processing plant and commercial abattoir were closed and operations consolidated elsewhere. The earthquake has prompted questions of whether or not regulations could change, or whether there is an opportunity to re-develop local processing capacity.

One of the ways in which Kaikoura is leveraging off this 'window of opportunity' is through its repositioning and rebranding as a tourism destination. Seeking to offer more than just marine wildlife viewing, it is attempting to reimagine itself as a year-round destination, with more diverse tourism options, targeting higher value, longer-staying visitors [69], with "food being more of a key component of the product and marketing for Kaikōura". As one informant, involved in local economic development put it:

For our resilience ... food and food branding is really important for Kaikōura, and it has been something of an area of diversification that we've looked at.... We have some amazing production that happens here, and there's a lot of stuff that's hidden here as well. A lot of people don't know that [we've] got olive oil and those sorts of things .... I mean we've got some amazing export beef and stuff that comes out of here. 
This viewpoint was shared by members of the business community who also recognised the value of food, and regional diversity. As a local business woman explained "I would love to see a reinventing of something around food and beverage":

Rather than a local view [we need] a much more regional view and because we've got the coastal environment we could tie that in with some wonderful seafood, you know, that could be our point of difference ... I think there is scope to run a really lovely seaside fête ... based around artisanal produce, based here, because we are halfway between Marlborough [at the north end of the S Island, famous for its wine] and Christchurch. We're sort of a natural gathering place. You could actually market it as a very special place to market special artisanal produce.

A focus on food might also help to bring diverse elements of the community together, as this informant continued:

Food brings rural and tourism together which is really important, because all the other tourism is mainly based around the sea and the harbour and everything else, so it is a way that our rural community can actually contribute.

In this way, transforming food networks reinforces the diversity of Kaikōura's brand proposition, while the demand for local food products and experiences from tourists helps ensure the economic sustainability of the food network.

\subsection{Transforming Community Action}

The second example of emergent transformation considers informal and formal response capability. In this example, the transformation is a direct response to the events of 14 November 2016, and its immediate aftermath.

Larina (Lilly) Tiffen, is a former trauma counsellor, with a catering business in North Canterbury, approximately $160 \mathrm{~km}$ south of Kaikoura. Following the earthquakes, she was concerned with the delivery of support for psychosocial wellbeing for rural residents in an area characterised by dispersed households and remote, isolated communities. Given her background, and her extensive networks in the community-developed through her catering work-she posted a message on Facebook asking for volunteers and donations. More than 2000 people replied. To manage the subsequent community-driven effort, she formed the 'Miss Lilly's Angels Trust' (hereafter, the Trust).

Larina and her team reacted to the challenges they saw. Helicopters were required in order to overcome the barriers of remoteness, damaged infrastructure, and logistical, however there was no comprehensive, or publicly available map of helicopter stations. Furthermore, affected rural households-particularly isolated hill-country stations-had voiced complaints about the long response times from government agencies and formal recovery bodies to their requests for help. Additional questions regarding a lack of familiarity with rural needs and concerns (such as animal health) were raised, along with opaque communication, and rigid protocols-“doing things a certain way" - which seemed inflexible.

To meet these challenges, the Trust rapidly capitalised on an extensive network to provide isolated rural households with large amounts of life essentials and provided a readily accessible line of communication for isolated communities. On the fifth and sixth day of the response, the Trust delivered 48 pallets of food and other goods via the HMNZS Canterbury, a navy frigate; five-and-a-half-tonnes of firewood, diesel, and care packages into the community of Goose Bay, south of Kaikōura whose road access had been cut off. The Trust team continued to process hundreds of Facebook messages, relaying communications between and for families in the affected areas. Most importantly, they could react to immediate, personal needs such as funeral arrangements. The Trust even helped reunite families that were separated after the earthquake and assisted a young mother unable to feed her child.

The Trust benefited not only from personal connections and relationships that existed prior to the earthquake, but also professional ones. The Trust quickly engaged with diverse professional groups, 
focused on trauma and recovery (e.g., NZ Response Teams, NZ Emergency Response Therapists); local businesses including commercial aviation companies, construction, freight and logistics providers; telecommunications services; international aid agencies (e.g., ShelterBox); NZ Police; and researchers.

While the Trust is anxious to develop detailed, place-based, peer-to-peer disaster response plans with rural communities, as well as promote a holistic view of mental health and wellbeing, and the impacts of isolation, there is perceived resistance to collaboration from established networks and actors, such as mandated authorities. For the Trust and others wishing to engage in resilience-building efforts, the experience of the Kaikōura earthquake has highlighted the need for greater coordination between formal and informal responders that focuses on the best solution for the greater good. Instead of going back to "baking her muffins" as Lilly was advised to do, the Trust continues to organise events aimed at bringing affected communities together, and they build on social media to coordinate and operate as a response and recovery network. Furthermore, they have self-published a book of stories from their community that narrates their own experiences of response, recovery, and preparation. Building on the momentum they have created, seeking further community buy-in and empowering new networks of responders, they have begun to make the personal experience of a hazard a political one.

It is quite common for altruism-based engagement to be insufficiently recognized at institutional levels [85]. Organisational as well as individual resistance to change is a natural part of the process (See e.g., Bovey \& Hede 2000 for an analysis of maladaptive responses at individual and organisational level. Various authors consider collaborative, adaptive co-governance. See e.g., Ison et al., 2014 for a framework on governance mechanisms for dealing with uncertainty and new dynamics, and Adger et al., 2009 and Folke et al., 2010 for an overview on adaptive governance.) [57,86]. The steady influence of institutions on behaviour can come as a barrier to transformation when conceptions of controlling and steering overshadow plurality for the sake of preserving an old status quo. Conceptually, transformation includes the dynamic interplay between persistence and change [30,34], leading to a reflexive structural shift-away from path dependencies and self-reinforcing feedbacks while working at multiple levels and recognising multi-scale and cross scale dynamics [87-89]. Effective management requires sustained local-institutional linkages through more systematic policy integration/mainstreaming across scales [85].

\section{Discussion and Conclusions}

The focus on transformation, resilience, and adaptation by scientific- and non-scientific communities, has produced new knowledge about their conceptualisation and theoretical abstraction $[32,33,56,90,91]$. Inquiring about their relevance and impact outside the conceptual domain requires insights into common characteristics, integrated strategies, and synergies [32,92]. In this paper, we have presented the implications of the resilience conceptualisation of transformation as multi-level, iterative adaptive cycles that exploit change pathways to cope with shocks and react to disturbances [31,34]. This perspective allows us to draw conclusions that critically reflect on New Zealand's transformation pathways in response to the Kaikōura earthquake.

Results from the two case studies show that harnessing existing relationships, collaborative groups, and social capital can create novel pathways for disaster risk reduction and enhance the effectiveness of existing ones. In other words: while disasters tend to strengthen social capital, they tend not to build new relationships between communities and organisations; those relationships are best established prior to an emergency. In New Zealand and elsewhere, social ties and recognition of the importance of place have had demonstrated resilience outcomes [8,25,93]. Accordingly, developing networks, fostering connections and promoting collaboration can all contribute to resilience pre- and post-disaster $[43,94,95]$. For example, the original group from the farmer's market network provided the basis for renewed debate and discussion about strengthening local food networks. Similarly, pre-existing relationships and contacts enabled the Trust to identify and respond more rapidly and effectively to rural needs than other organisations, who may have lacked the readily accessible networks with affected communities. 
Transformative capacity emerges when space for informal networks that provide strategic and operational innovation is created, which can also catalyse new types of governance arrangements and structures [96]. By ignoring the complexity of emerging perspectives-particularly at the local level—during the response to a disaster, governance arrangements fail to take advantage of adaptive capacity and innovation potential. Instead, such arrangements cement existing maladaptation, actor constellations, and the associated action and policy gaps. In such cases, the capacity for transformation and the ability to sustain transformative processes becomes negligible.

The capacity to transform governance structures in Aotearoa-New Zealand is currently limited by the scale and structures of decision-making and the static framing of risks and responses [97]. While regional and local authorities are required to consider natural hazards-a matter of national importance under the 2017 Amendments of the Resource Management Act, which provides the legislative framework for natural resource policy in New Zealand-their power to directly support local communities and encourage contributions by non-governmental actors as a part of multilevel, participatory structures in relation to hazards are limited [8]. Such frameworks hinder informal actors, agents, and institutions such as the Trust from providing assistance-no matter how well-intentioned.

In an analysis of institutional practice barriers and enablers, Lawrence and colleagues [97] found that "the disciplinary practices of law, engineering and planning, within legal frameworks, result in the use of static mechanisms which create inflexible responses to changing risk". This is supported by Harker, Taylor, and Knight-Lenihan [98], who point to the co-ordinated and deliberate trend away from multi-level governance in New Zealand, resulting in lost opportunities, a lack of integration, oversight, or coordination of strategic actions. This is also evident in regulatory restrictions that are inflexible, even during a crisis. Generating insight into the variability between short-term willingness to adopt atypical responses versus the flexibility to accept longer-term change processes could shed some light on the interplay of these dimensions and their impact on the potential for transformation. This could clarify dynamics of retaining control across those political, socio-economic, and cultural dimensions of risk recovery and preparedness as well as ways of overcoming and asserting power at different levels of decision-making to reimagining structures and behavioural patterns in the face of hazards.

The case studies also highlight the ways in which globalised supply chains and the rationalisation of processing facilities have affected rural communities in Aotearoa-New Zealand and elsewhere, with implications for resilience and vulnerability. The loss of the milk factory and commercial abattoir from Kaikoura for example, not only resulted in local job losses and subsequent population decline [99], but eroded the connection between local communities and the food grown there. The earthquake highlighted local food security issues and revealed the extent to which Kaikōura residents had lost their access to, and knowledge of, what was being produced in the region. Emerging post-quake initiatives reveal a resolve to strengthen and sustain local food networks, encouraging diversified production, modified agricultural practices, and robust linkages in the food supply-chain [100,101]. At the same time, incorporating food into the town's tourism offerings will help diversify the economy [102]. Strengthening representations and stories of the social and cultural heritage of local food [103] may also enhance social connectivity, community capacity, and other attributes of community resilience [104-106]. There is need in particular to broaden the respresentation-and study—of traditional and indigenous food networks, which played an important role in the recovery effort [107]. Continuing and expanded research in the region will document the development of these networks and relationships, evaluate learning and levels of emergency preparedness, and the ways in which other community initiatives are emerging as part of the overall response and recovery effort.

Finally, New Zealand's volunteers and community responses are expansive. What is currently lacking however is their institutionalisation, formal interaction, and recognition. Volunteers have a role in disaster recovery, but they also have the potential to reimage structures, processes, and relationships. Based on the cases discussed here, transformation in accordance with and reaction to hazards is also partly determined by the chances of-and incentives for-different stakeholders to become involved in what is currently considered a national affair. 
What states can and cannot do is by now an old discussion. Work on governing and governance beyond, without, or above the state has proliferated. In that context, questions are often raised about the optimal level of decision-making. To foster agreement and "bridge the gap between decisionmakers [sic] and those affected by decisions" [108], interactions between governmental actors, citizens, non-governmental organisations, and multilateral agencies have increased, creating new structures of involvement and decision making in the process. It may be possible to fully capitalise on the shifting equilibrium following disaster and realise the opportunities for transformation towards greater resilience in part by acknowledging the contributions and particular role for bottom-up inputs into the governance system, fostering longer-lasting interaction between policy makers and stakeholders and establishing inter-organizational arrangements to introduce a polycentric system structure $[109,110]$.

Author Contributions: N.A.C.-H. conceptualised the paper and coordinated drafting of the manuscript. N.A.C.-H., J.F. and F.B. wrote the paper. All authors approved the final submission.

Funding: This research was funded by the Resilience to Nature's Challenges National Science Challenge through the NZ Ministry of Business Innovation and Employment, as part of the Rural Co-Creation Laboratory.

Acknowledgments: Two anonymous reviewers provided valuable feedback which has improved the quality of the paper. The authors are grateful for the valuable insight and generous time donated by members of the Kaikoura community, including local government staff, businesses, and other stakeholders. Special thanks to Larina Tiffin for her willingness to share her story, and to Andrea Grant (SCION) for facilitating.

Conflicts of Interest: The authors declare no conflict of interest.

\section{References}

1. Adger, W.N.; Hughes, T.P.; Folke, C.; Carpenter, S.R.; Rockström, J. Social-Ecological Resilience to Coastal Disasters. Science 2005, 309, 1036-1039. [CrossRef] [PubMed]

2. Cutter, S.L.; Ash, K.D.; Emrich, C.T. The geographies of community disaster resilience. Glob. Environ. Chang. 2014, 29, 65-77. [CrossRef]

3. Tanner, T.; Lewis, D.; Wrathall, D.; Bronen, R.; Cradock-Henry, N.; Huq, S.; Lawless, C.; Nawrotzki, R.; Prasad, V.; Rahman, M.A.; et al. Livelihood resilience in the face of climate change. Nat. Clim. Chang. 2015, 5, 23-26. [CrossRef]

4. Gall, M.; Borden, K.A.; Emrich, C.T.; Cutter, S.L. The Unsustainable Trend of Natural Hazard Losses in the United States. Sustainability 2011, 3, 2157-2181. [CrossRef]

5. Cutter, S.L.; Ismail-Zadeh, A.; Alcántara-Ayala, I.; Altan, O.; Baker, D.N.; Briceño, S.; Gupta, H.; Holloway, A.; Johnston, D.; McBean, G.A.; et al. Global risks: Pool knowledge to stem losses from disasters. Nature 2015, 522, 277-279. [CrossRef] [PubMed]

6. Solecki, W. Hurricane Sandy in New York, extreme climate events and the urbanization of climate change: Perspectives in the context of sub-Saharan African cities. Curr. Opin. Environ. Sustain. 2015, 13, 88-94. [CrossRef]

7. Birkmann, J.; Buckle, P.; Jaeger, J.; Pelling, M.; Setiadi, N.; Garschagen, M.; Fernando, N.; Kropp, J. Extreme events and disasters: A window of opportunity for change? Analysis of organizational, institutional and political changes, formal and informal responses after mega-disasters. Nat. Hazards 2010, 55, 637-655. [CrossRef]

8. Spector, S.; Cradock-Henry, N.A.; Beaven, S.; Orchiston, C. Characterising rural resilience in New Zealand: A systematic review. Reg. Environ. Chang. 2018, in press.

9. Basher, R. High Stakes-Disaster Risk in New Zealand. Policy Q. 2016, 12, 25-29.

10. Stevenson, J.R.; Kachali, H.; Whitman, Z.; Seville, E.; Vargo, J.; Wilson, T. Preliminary observations of the impacts the 22 February Christchurch Earthquake had on organisations and the economy: A report from the field (22 February-22 March 2011). Bull. N. Z. Soc. Earthq. Eng. 2011, 44, 65.

11. Hayward, B.M. Rethinking Resilience: Reflections on the Earthquakes in Christchurch, New Zealand, 2010 and 2011. Ecol. Soc. 2013, 18. [CrossRef] 
12. Fry, B.; Benites, R.; Reyners, M.; Holden, C.; Kaiser, A.; Bannister, S.; Gerstenberger, M.; Williams, C.; Ristau, J.; Beavan, J. Strong shaking in recent New Zealand earthquakes. Eos Trans. Am. Geophys. Union 2011, 92, 349-351. [CrossRef]

13. Stirling, M.; McVerry, G.; Gerstenberger, M.; Litchfield, N.; Dissen, R.V.; Berryman, K.; Barnes, P.; Wallace, L.; Villamor, P.; Langridge, R.; et al. National Seismic Hazard Model for New Zealand: 2010 Update. Bull. Seismol. Soc. Am. 2012, 102, 1514-1542. [CrossRef]

14. Kaiser, A.; Balfour, N.; Fry, B.; Holden, C.; Litchfield, N.; Gerstenberger, M.; D'Anastasio, E.; Horspool, N.; McVerry, G.; Ristau, J.; et al. The 2016 Kaikōura, New Zealand, Earthquake: Preliminary Seismological Report. Seismol. Res. Lett. 2017, 88, 727-739. [CrossRef]

15. Bradley, B.A.; Wotherspoon, L.M.; Kaiser, A.E. Ground motion and site effect observations in the Wellington Region from the $2016 \mathrm{M}_{\mathrm{W}} 7.8$ Kaikoura, New Zealand earthquake. Bull. N. Z. Soc. Earthq. Eng. 2017, 50, 94-105.

16. Stevenson, J.R.; Becker, J.; Cradock-Henry, N.; Johal, S.; Johnston, D.; Seville, E. Economic and Social Reconnaissance: Kaikōura Earthquake 2016. Bull. N. Z. Soc. Earthq. Eng. 2017, 50, 343-351.

17. Bradley, B.; Razafindrakoto, H.N.T.; Nazer, M.A. Strong ground motion observations of engineering interest from the 14 November 2016 Mw7.8 Kaikōura, New Zealand earthquake. Bull. N. Z. Soc. Earthq. Eng. 2017, 50, 85-93.

18. McDonald, G.; Smith, N.; Ayers, M.; Kim, J.H. Economic Impact of the 2016 Kaikoura Earthquake: A Report Prepared for the Ministry of Transport; Ministry of Transport: Wellington, New Zealand, 2017.

19. Orense, R.P.; Mirjafari, Y.; Asadi, S.; Naghibi, M.; Chen, X.; Altaf, O.; Asadi, B. Ground performance in Wellington waterfront area following the 2016 Kaikoura earthquake. Bull. N. Z. Soc. Earthq. Eng. 2017, 50, 142-151.

20. Hughes, M.W.; Nayyerloo, M.; Bellagamba, X.; Morris, J.; Brabhaharan, P.; Rooney, S.; Hobbs, E.; Wooley, K.; Hutchison, S. Impacts of the 14th November 2016 Kaikōura earthquake on Three Waters Systems in Wellington, Marlborough and Kaikōura: Preliminary Observations. Bull. N. Z. Soc. Earthq. Eng. 2017, $12,962$.

21. Davies, A.J.; Sadashiva, V.; Aghababaei, M.; Barnhill, D.; Costello, S.B.; Fanslow, B.; Headifen, D.; Hughes, M.; Kotze, R.; Mackie, J.; et al. Transport Infrastructure Performance and Management in the South Island of New Zealand, During the First 100 Days Following the $2016 \mathrm{M}_{\mathrm{W}} 7.8$ “Kaikoura” Earthquake. Bull. N. Z. Soc. Earthq. Eng. 2017, 50, 271-299.

22. Bradley, G. Tourist Industry in Damage Control after Earthquakes. Available online: https://www.nzherald. co.nz/business /news/article.cfm?c_id=3\&objectid=11748568 (accessed on 6 May 2018).

23. Thompson, M.A.; Owen, S.; Lindsay, J.M.; Leonard, G.S.; Cronin, S.J. Scientist and stakeholder perspectives of transdisciplinary research: Early attitudes, expectations, and tensions. Environ. Sci. Policy 2017, 74, 30-39. [CrossRef]

24. Hufschmidt, G.; Crozier, M.J. Evolution of natural risk: Analysing changing landslide hazard in Wellington, Aotearoa/New Zealand. Nat. Hazards 2008, 45, 255-276. [CrossRef]

25. Jakes, P.J.; Langer, E.R. (Lisa) The adaptive capacity of New Zealand communities to wildfire. Int. J. Wildland Fire 2012, 21, 764. [CrossRef]

26. Lawrence, J.; Reisinger, A.; Mullan, B.; Jackson, B. Exploring climate change uncertainties to support adaptive management of changing flood-risk. Environ. Sci. Policy 2013, 33, 133-142. [CrossRef]

27. Cradock-Henry, N.A. New Zealand kiwifruit growers' vulnerability to climate and other stressors. Reg. Environ. Chang. 2017, 17, 245-259. [CrossRef]

28. Orchiston, C.; Higham, J.E.S. Knowledge management and tourism recovery (de)marketing: The Christchurch earthquakes 2010-2011. Curr. Issues Tour. 2016, 19, 64-84. [CrossRef]

29. Sovacool, B.K. Don't let disaster recovery perpetuate injustice. Nat. News 2017, 549, 433. [CrossRef] [PubMed]

30. Walker, B.; Holling, C.S.; Carpenter, S.; Kinzig, A. Resilience, adaptability and transformability in social-ecological systems. Ecol. Soc. 2004, 9, 5. [CrossRef]

31. Walker, B.H.; Abel, N.; Anderies, J.M.; Ryan, P. Resilience, adaptability, and transformability in the Goulburn-Broken Catchment, Australia. Ecol. Soc. 2009, 14, 12. [CrossRef]

32. Feola, G. Societal transformation in response to global environmental change: A review of emerging concepts. Ambio 2015, 44, 376-390. [CrossRef] [PubMed] 
33. Clément, V.; Rivera, J. From Adaptation to Transformation: An Extended Research Agenda for Organizational Resilience to Adversity in the Natural Environment. Organ. Environ. 2017, 30, 346-365. [CrossRef]

34. Folke, C.; Carpenter, S.R.; Walker, B.; Scheffer, M.; Chapin, T.; Rockström, J. Resilience Thinking: Integrating Resilience, Adaptability, and Transformability. Ecol. Soc. 2010, 15, 20. [CrossRef]

35. Miller, F.; Osbahr, H.; Boyd, E.; Thomalla, F.; Bharwani, S.; Ziervogel, G.; Walker, B.; Birkmann, J.; van der Leeuw, S.; Rockström, J.; et al. Resilience and Vulnerability: Complementary or Conflicting Concepts? Ecol. Soc. 2010, 15. [CrossRef]

36. Brown, K.; Westaway, E. Agency, Capacity, and Resilience to Environmental Change: Lessons from Human Development, Well-Being, and Disasters. Annu. Rev. Environ. Resour. 2011, 36, 321-342. [CrossRef]

37. Djalante, R.; Holley, C.; Thomalla, F.; Carnegie, M. Pathways for adaptive and integrated disaster resilience. Nat. Hazards 2013, 69, 2105-2135. [CrossRef]

38. Morecroft, M.D.; Crick, H.Q.P.; Duffield, S.J.; Macgregor, N.A. Resilience to climate change: Translating principles into practice. J. Appl. Ecol. 2012, 49, 547-551. [CrossRef]

39. Cooper-Cabell, N. Mind the gap: Post earthquake community wellbeing? Aotearoa N. Z. Soc. Work 2016, 25, 27-34. [CrossRef]

40. Höfler, M. Psychological Resilience Building in Disaster Risk Reduction: Contributions from Adult Education. Int. J. Disaster Risk Sci. 2014, 5, 33-40. [CrossRef]

41. Mitchell, M.; Griffith, R.; Ryan, P.; Walkerden, G.; Walker, B.; Brown, V.A.; Robinson, S. Applying Resilience Thinking to Natural Resource Management through a "Planning-By-Doing" Framework. Soc. Nat. Resour. 2014, 27, 299-314. [CrossRef]

42. Baird, J.; Plummer, R.; Moore, M.-L.; Brandes, O. Introducing Resilience Practice to Watershed Groups: What Are the Learning Effects? Soc. Nat. Resour. 2016, 29, 1214-1229. [CrossRef]

43. Cradock-Henry, N.A.; Greenhalgh, S.; Brown, P.; Sinner, J. Factors influencing successful collaboration for freshwater management in Aotearoa, New Zealand. Ecol. Soc. 2017, 22, 14. [CrossRef]

44. De Goede, D.M.; Gremmen, B.; Blom-Zandstra, M. Robust agriculture: Balancing between vulnerability and stability. NJAS Wagening. J. Life Sci. 2013, 64-65, 1-7. [CrossRef]

45. Carter, N.; Viña, A.; Hull, V.; McConnell, W.; Axinn, W.; Ghimire, D.; Liu, J. Coupled human and natural systems approach to wildlife research and conservation. Ecol. Soc. 2014, 19. [CrossRef]

46. Turner, B., II; Esler, K.J.; Bridgewater, P.; Tewksbury, J.; Sitas, N.; Abrahams, B.; Chapin, F.S., III; Chowdhury, R.R.; Christie, P.; Diaz, S.; et al. Socio-Environmental Systems (SES) Research: What have we learned and how can we use this information in future research programs. Curr. Opin. Environ. Sustain. 2016, 19, 160-168. [CrossRef]

47. Anderies, J.M.; Janssen, M.A. The fragility of robust social-ecological systems. Glob. Environ. Chang. 2011, 21, 1153-1156. [CrossRef]

48. Gunderson, L.H. Ecological Resilience-in Theory and Application. Annu. Rev. Ecol. Syst. 2000, 31, 425-439. [CrossRef]

49. Walker, B.H.; Salt, D. Resilience Practice: Building Capacity to Absorb Disturbance and Maintain Function; Island Press: Washington, DC, USA, 2012; ISBN 978-1-59726-801-1.

50. Gunderson, L.H.; Holling, C.S. (Eds.) Panarchy: Understanding Transformations in Human and Natural Systems; Island Press: Washington, DC, USA, 2002; ISBN 1-55963-856-7.

51. Holling, C.S. Understanding the Complexity of Economic, Ecological, and Social Systems. Ecosystems 2001, 4, 390-405. [CrossRef]

52. Goldstein, B.E. (Ed.) Collaborative Resilience: Moving through Crisis to Opportunity; MIT Press: Cambridge, MA, USA, 2012; ISBN 978-0-262-01653-7.

53. Adger, W.N.; Dessai, S.; Goulden, M.; Hulme, M.; Lorenzoni, I.; Nelson, D.R.; Naess, L.O.; Wolf, J.; Wreford, A. Are there social limits to adaptation to climate change? Clim. Chang. 2009, 93, 335-354. [CrossRef]

54. Matyas, D.; Pelling, M. Positioning resilience for 2015: The role of resistance, incremental adjustment and transformation in disaster risk management policy. Disasters 2015, 39, s1-s18. [CrossRef] [PubMed]

55. Brundiers, K.; Eakin, H.C. Leveraging Post-Disaster Windows of Opportunities for Change towards Sustainability: A Framework. Sustainability 2018, 10, 1390. [CrossRef]

56. Abson, D.J.; Fischer, J.; Leventon, J.; Newig, J.; Schomerus, T.; Vilsmaier, U.; Von Wehrden, H.; Abernethy, P.; Ives, C.D.; Jager, N.W.; et al. Leverage points for sustainability transformation. Ambio 2017, 46, 30-39. [CrossRef] [PubMed] 
57. O'Brien, K. Global environmental change II From adaptation to deliberate transformation. Prog. Hum. Geogr. 2012, 36, 667-676. [CrossRef]

58. Colloff, M.J.; Martín-López, B.; Lavorel, S.; Locatelli, B.; Gorddard, R.; Longaretti, P.-Y.; Walters, G.; van Kerkhoff, L.; Wyborn, C.; Coreau, A.; et al. An integrative research framework for enabling transformative adaptation. Environ. Sci. Policy 2017, 68, 87-96. [CrossRef]

59. Blair, B.; Lovecraft, A.L.; Hum, R. The Disaster Chronotope: Spatial and Temporal Learning in Governance of Extreme Events. In Governance of Risk, Hazards and Disasters: Trends in Theory and Practice; Forino, G., Bonati, S., Calandra, L.M., Eds.; Routledge: New York, NY, USA, 2018; pp. 43-65. ISBN 978-1-138-20682-3.

60. Adger, W.N.; Barnett, J.; Brown, K.; Marshall, N.; O'Brien, K. Cultural dimensions of climate change impacts and adaptation. Nat. Clim. Chang. 2013, 3, 112-117. [CrossRef]

61. Nursey-Bray, M.; Harvey, N.; Smith, T.F. Learning and local government in coastal South Australia: Towards a community of practice framework for adapting to global change. Reg. Environ. Chang. 2016, 16, 733-746. [CrossRef]

62. Brunner, R.; Lynch, A. Adaptive Governance and Climate Change; American Meteorological Society: Boston, MA, USA, 2013.

63. Pahl-Wostl, C. The Importance of Social Learning in Restoring the Multifunctionality of Rivers and Floodplains. Ecol. Soc. 2006, 11. [CrossRef]

64. Folke, C. Resilience: The emergence of a perspective for social-ecological systems analyses. Glob. Environ. Chang. 2006, 16, 253-267. [CrossRef]

65. Smit, B.; Pilifosova, O. From Adaptation to Adaptive Capacity and Vulnerability Reduction. In Climate Change, Adaptive Capacity and Development; Imperial College Press: London, UK; World Scientific Publishing Co.: Singapore, 2003; pp. 9-28. ISBN 978-1-86094-373-7.

66. Ison, R.; Grant, A.; Bawden, R. Scenario Praxis for Systemic Governance: A Critical Framework. Environ. Plan. C Gov. Policy 2014, 32, 623-640. [CrossRef]

67. Dobson, A. Citizens, citizenship and governance for sustainability. In Governing Sustainability; Adger, W.N., Jordan, A., Eds.; Cambridge University Press: Cambridge, UK, 2009; pp. 125-141. ISBN 978-0-511-80775-6.

68. Sjöstedt, M. Resilience revisited: Taking institutional theory seriously. Ecol. Soc. 2015, 20. [CrossRef]

69. Kaikoura District Council. Reimagine Kaikoura Pōhewatia anō a Kaikōura; Kaikoura District Council: Kaikoura, New Zealand, 2017; p. 56.

70. Horn, C.; Simmons, D. Community adaptation to tourism: Comparisons between Rotorua and Kaikoura, New Zealand. Tour. Manag. 2002, 23, 133-143. [CrossRef]

71. Higham, J.; Bejder, L.; Williams, R. Whale-Watching: Sustainable Tourism and Ecological Management; Cambridge University Press: Cambridge, UK, 2014; ISBN 978-0-521-19597-3.

72. Ministry of Business, Innovation and Employment. Key Tourism Statistics for Kaikoura and Hurunui Districts. Available online: http:/ / www.mbie.govt.nz/info-services/sectors-industries/tourism/tourismresearch-data/key-tourism-statistics-for-kaikoura-and-hurunui-districts (accessed on 6 May 2018).

73. Phibbs, S.; Kenney, C.; Solomon, M. Ngā Mōwaho: An analysis of Māori responses to the Christchurch earthquakes. Kōtuitui N. Z. J. Soc. Sci. Online 2015, 10, 72-82. [CrossRef]

74. Berg, B.L.; Lune, H. Qualitative Research Methods for the Social Sciences, 9th ed.; Pearson: Boston, MA, USA, 2017; ISBN 978-0-13-420213-6.

75. Bloor, M.; Frankland, J.; Thomas, M.; Robson, K. Focus Groups in Social Research; SAGE Publications Ltd: London, UK, 2001; ISBN 978-0-7619-5742-3.

76. Ford, J.D.; Keskitalo, E.C.H.; Smith, T.; Pearce, T.; Berrang-Ford, L.; Duerden, F.; Smit, B. Case study and analogue methodologies in climate change vulnerability research. Wiley Interdiscip. Rev. Clim. Chang. 2010, 1, 374-392. [CrossRef]

77. Martin, P.C.M.; Nunn, P.; Leon, J.; Tindale, N. Responding to multiple climate-linked stressors in a remote island context: The example of Yadua Island, Fiji. Clim. Risk Manag. 2018. [CrossRef]

78. Marshall, N.A.; Dowd, A.-M.; Fleming, A.; Gambley, C.; Howden, M.; Jakku, E.; Larsen, C.; Marshall, P.A.; Moon, K.; Park, S.; et al. Transformational capacity in Australian peanut farmers for better climate adaptation. Agron. Sustain. Dev. 2014, 34, 583-591. [CrossRef]

79. Babbie, E.R. The Practice of Social Research, 13th ed; Wadsworth Publishing: Belmont, CA, USA, 2012; ISBN 978-1-133-04979-1.

80. Braun, V.; Clarke, V. Using thematic analysis in psychology. Qual. Res. Psychol. 2006, 3, 77-101. [CrossRef] 
81. Challis, A.J. The Nelson Marlborough Region: An Archaeological Synthesis; New Zealand Archaeological Association: Dunedin, New Zealand, 1991.

82. Solecki, W.D.; Michaels, S. Looking through the postdisaster policy window. Environ. Manag. 1994, 18, 587-595. [CrossRef]

83. Farley, J.; Baker, D.; Batker, D.; Koliba, C.; Matteson, R.; Mills, R.; Pittman, J. Opening the policy window for ecological economics: Katrina as a focusing event. Ecol. Econ. 2007, 63, 344-354. [CrossRef]

84. Goldstein, B.E. Skunkworks in the Embers of the Cedar Fire: Enhancing Resilience in the Aftermath of Disaster. Hum. Ecol. 2008, 36, 15-28. [CrossRef]

85. Wamsler, C.; Raggers, S. Principles for supporting city-citizen commoning for climate adaptation: From adaptation governance to sustainable transformation. Environ. Sci. Policy 2018, 85, 81-89. [CrossRef]

86. Bovey, W.H.; Hede, A. Resistance to organisational change: The role of defence mechanisms. J. Manag. Psychol. 2001, 16, 534-548. [CrossRef]

87. Meadowcroft, J. What about the politics? Sustainable development, transition management, and long term energy transitions. Policy Sci. 2009, 42, 323. [CrossRef]

88. Geels, F.W.; Schot, J. Typology of sociotechnical transition pathways. Res. Policy 2007, 36, 399-417. [CrossRef]

89. Olsson, P.; Galaz, V.; Boonstra, W.J. Sustainability transformations: A resilience perspective. Ecol. Soc. 2014, 19, 1. [CrossRef]

90. Bahadur, A.; Tanner, T. Transformational resilience thinking: Putting people, power and politics at the heart of urban climate resilience. Environ. Urban. 2014, 26, 200-214. [CrossRef]

91. O'Brien, K.L. Climate change and social transformations: Is it time for a quantum leap? WIREs Clim. Chang. 2016. [CrossRef]

92. O'Connell, D.; Walker, B.; Abel, N.; Grigg, N.; Cowie, A.; Durón, G. An Introduction to the Resilience, Adaptation Pathways and Transformation Assessment (RAPTA) Framework; CSIRO: Canberra, Australia, 2015; p. 96.

93. Marshall, N.A.; Park, S.E.; Adger, W.N.; Brown, K.; Howden, S.M. Transformational capacity and the influence of place and identity. Environ. Res. Lett. 2012, 7, 034022. [CrossRef]

94. Whitman, Z.R.; Wilson, T.M.; Seville, E.; Vargo, J.; Stevenson, J.R.; Kachali, H.; Cole, J. Rural organizational impacts, mitigation strategies, and resilience to the 2010 Darfield earthquake, New Zealand. Nat. Hazards 2013, 69, 1849-1875. [CrossRef]

95. Johnston, D.; Becker, J.; Paton, D. Multi-agency community engagement during disaster recovery: Lessons from two New Zealand earthquake events. Disaster Prev. Manag. 2012, 21, 252-268. [CrossRef]

96. Hölscher, K.; Frantzeskaki, N.; Loorbach, D. Steering transformations under climate change: Capacities for transformative climate governance and the case of Rotterdam, the Netherlands. Reg. Environ. Chang. 2018, 1-15. [CrossRef]

97. Lawrence, J.; Sullivan, F.; Lash, A.; Ide, G.; Cameron, C.; McGlinchey, L. Adapting to changing climate risk by local government in New Zealand: Institutional practice barriers and enablers. Local Environ. 2015, 20, 298-320. [CrossRef]

98. Harker, J.; Taylor, P.; Knight-Lenihan, S. Multi-level governance and climate change mitigation in New Zealand: Lost opportunities. Clim. Policy 2017, 17, 485-500. [CrossRef]

99. Hall, C.M. Rural wine and food tourism cluster and network development. In Rural Tourism and Sustainable Business; Hall, D.R., Kirkpatrick, I., Mitchell, M., Eds.; Channel View: Clevedon, UK, 2005; pp. 149-164.

100. Everett, S.; Slocum, S.L. Food and tourism: An effective partnership? A UK-based review. J. Sustain. Tour. 2013, 21, 789-809. [CrossRef]

101. Ilbery, B.; Maye, D. Alternative (Shorter) Food Supply Chains and Specialist Livestock Products in the Scottish-English Borders. Environ. Plan. A 2005, 37, 823-844. [CrossRef]

102. Hjalager, A.-M.; Richards, G. (Eds.) Tourism and Gastronomy, 1st ed.; Routledge: London, UK; New York, NY, USA, 2011; ISBN 978-0-415-51099-8.

103. Everett, S.; Aitchison, C. The Role of Food Tourism in Sustaining Regional Identity: A Case Study of Cornwall, South West England. J. Sustain. Tour. 2008, 16, 150-167. [CrossRef]

104. Aldrich, D.P.; Meyer, M.A. Social Capital and Community Resilience. Am. Behav. Sci. 2015, 59, $254-269$. [CrossRef]

105. Mackay, M.; Fountain, J.; Cradock-Henry, N.A. Festivals as devices for enhancing social connectivity and the resilience of rural communities. In Routledge Handbook of Festivals; Mair, J., Ed.; Routledge: London, UK, 2018. 
106. Maclean, K.; Cuthill, M.; Ross, H. Six attributes of social resilience. J. Environ. Plan. Manag. 2014, 57, $144-156$. [CrossRef]

107. Towle, M. “We're Here to Help, We'll Help Anybody”. Available online: https:/ /www.radionz.co.nz/news / national/318520/\%27we\%27re-here-to-help,-we\%27ll-help-anybody\%27 (accessed on 8 June 2018).

108. Adger, W.N.; Brown, K.; Fairbrass, J.; Jordan, A.; Paavola, J.; Rosendo, S.; Seyfang, G. Governance for sustainability: Towards a "thick" analysis of environmental decisionmaking. Environ. Plan. A 2003, 35, 1095-1110. [CrossRef]

109. Ostrom, E. Governing the Commons: The Evolution of Institutions for Collective Action; The Political economy of Institutions and Decisions; Cambridge University Press: Cambridge, UK; New York, NY, USA, 1990; ISBN 978-0-521-37101-8.

110. Bowen, K.J.; Cradock-Henry, N.A.; Koch, F.; Patterson, J.; Häyhä, T.; Vogt, J.; Barbi, F. Implementing the "sustainable Development Goals": Towards Addressing Three Key Governance Challenges—Collective Action, Trade-Offs, and Accountability. Curr. Opin. Environ. Sustain. 2017, 26-27, 90-96. [CrossRef]

(C) 2018 by the authors. Licensee MDPI, Basel, Switzerland. This article is an open access article distributed under the terms and conditions of the Creative Commons Attribution (CC BY) license (http:/ / creativecommons.org/licenses/by/4.0/). 